\title{
Effect of Dietary Energy to Protein Ratios on Growth Performance and Feed Efficiency of Juvenile Grass Carp (Ctenopharyngodon idella)
}

\author{
Zhen-Yu Du ${ }^{1,2}$, Li-Xia Tian $^{1}$, Gui-Ying Liang ${ }^{1}$ and Yong-Jian Liu ${ }^{1 *}$ \\ ${ }^{1}$ Institute of Aquatic Economic Animals, Sun Yat-sen University, 510275 Guangzhou, P.R. China \\ ${ }^{2}$ National Institute of Nutrition and Seafood Research (NIFES), Nordnesboder 2, 5005 Bergen, Norway
}

\begin{abstract}
A feeding trial of three dietary protein (DP) (25, 35 and 45\%) and four dietary lipid (DL) levels (3, 6, 9 and $12 \%$ ) with different dietary energy to protein (E/P) ratios (from 5.93 to $13.84 \mathrm{kcal} / \mathrm{g}$ protein) was conducted to investigate the proper dietary E/P ratio for juvenile grass carp. After acclimation of 2 weeks by a lipid-free diet, fish were reared for 10 weeks in a water recirculation system at $22.2 \pm 2.8^{\circ} \mathrm{C}$ under natural light-dark cycle. The highest growth and feed efficiency were obtained with the diet of 45\% DP and 3\% DL (E/P ratio of $5.93 \mathrm{kcal} / \mathrm{g}$ protein), followed closely by the group with 35\% DP and 3\% DL (E/P ratio of $7.62 \mathrm{kcal} / \mathrm{g}$ protein), without any significant difference between them. At the same DP level, growth and feed efficiency decreased with increasing DL level. However, at the same DL level, growth and feed efficiency enhanced with increasing DP level. But at the 9\% and 12\% DL level (energy of 321 and $348 \mathrm{kcal} / 100 \mathrm{~g}$ diet), there were no significant differences between groups in terms of growth indices, irrespective of the DP level. Except intraperitoneal fat ratio, condition factor, viscera ratio and hepatosomatic index, all studied parameters showed increasing trends with enhancing dietary E/P ratio. Lipid contents of whole body and liver aroused with the increase of DL level at the same DP level. Taking into account the cost of feeding, the diet containing 35\% DP and 3\% DL (E/P ratio of 7.62 $\mathrm{kcal} / \mathrm{g}$ protein, GE of $267 \mathrm{kcal} / 100 \mathrm{~g}$ diet) is recognized as an optimal diet for juvenile grass carp in the present study. However, some future investigations will need to address the effects of temperature on optimal E/P ratio in grass carp.
\end{abstract}

Keywords: Grass carp; energy to protein ratio; growth; feed efficiency.

\section{INTRODUCTION}

In fish nutrition, dietary protein is the most important factor affecting growth performance of fish and feed cost [1], but excessive amount of dietary protein could cause the increase of ammonia excretion. Dietary protein utilization may be improved by partially replacing dietary protein with lipid and/or carbohydrate to benefit from protein-sparing criterion [2]. However, excessive energy in the diet can lead to increase body lipid deposition and to reduce growth [3]. Therefore, dietary energy to protein $(\mathrm{E} / \mathrm{P})$ ratio is an important index in fish feed formulation. The optimal dietary E/P ratio $(\mathrm{kcal} / \mathrm{g}$ protein) has been determined in some aquatic animal species including channel catfish, 11.5 [4]; Nile tilapia, 9.1 [5]; blue tilapia, 9.3 [6]; hybrid striped bass, 8 [7]; African catfish, 6.9 [8] and Asian seabass, 7.8 [9].

As a typical herbivorous and stomachless finfish, grass carp is one of the most popular fish species for aquaculture in China throughout the year. Although protein and energy requirement of grass carp have been already studied [10-17], the data of dietary E/P ratio is not complete, especially in the cold seasons. Because grass carp normally grows slowly in lower temperatures, a study to demonstrate the optimum dietary $\mathrm{E} / \mathrm{P}$ ratio would help to improve the growth of grass

*Address correspondence to these authors at the National Institute of Nutrition and Seafood Research (NIFES), Postboks 2029 Nordnes, 5817 Bergen, Norway; Tel: +47 91132279; Fax: +47 55905298; E-mail: zdu@nifes.no; Institute of Aquatic Economic Animals, Sun Yat-sen University, 510275 Guangzhou, P.R. China; Tel: +86 84110789; E-mail: edls@mail.sysu.edu.cn carp in low temperatures. The objective of the present study was to determine the effect of dietary E/P ratio on growth, protein efficiency ratio and body composition of juvenile grass carp during the cold seasons.

\section{MATERIALS AND METHODOLOGY}

\section{Diet Preparation}

12 purified diets with different $\mathrm{E} / \mathrm{P}$ ratios were prepared as described by [18], and were stored at $-30^{\circ} \mathrm{C}$ until use. The formulation of diets was shown in Table $\mathbf{1}$. The available energy was calculated using physiological fuel value of 4.0, 4.0 and $9.0 \mathrm{kcal} \cdot \mathrm{g}^{-1}\left(16.7,16.7\right.$ and $\left.37.7 \mathrm{KJ} \cdot \mathrm{g}^{-1}\right)$ for protein, carbohydrate and lipid respectively $[19,20]$.

\section{Supply and Maintenance of Fish}

Juvenile grass carp were obtained from our own fish farm and maintained in 36 circular fiberglass tanks $(120 \mathrm{~L})$ in a half-indoor room under natural light-dark cycle. The fish were acclimated to experimental conditions and feed for 2 weeks. During the acclimating period, fish were fed with lipid-free experimental diet (GE $2312 \mathrm{kcal} \cdot \mathrm{kg}^{-1}$ ) at $1 \%$ body weight per day (BW/d). After acclimation period, healthy fish with similar body weight were selected for the experiment, with 20 fish per tank. The fish were weighed and the differences in tanks were no more than $5 \%$. The initial weight of fish was $3.30 \pm 0.03 \mathrm{~g}$. Fish were fed four times a day (9:00AM, 12:00AM, 3:00PM, 6:00PM). The feeding rate was $2.0 \% \mathrm{BW} / \mathrm{d}$. Fish were weighed every two weeks 
Table 1. Composition of Experimental Diets (\% dry Weight)

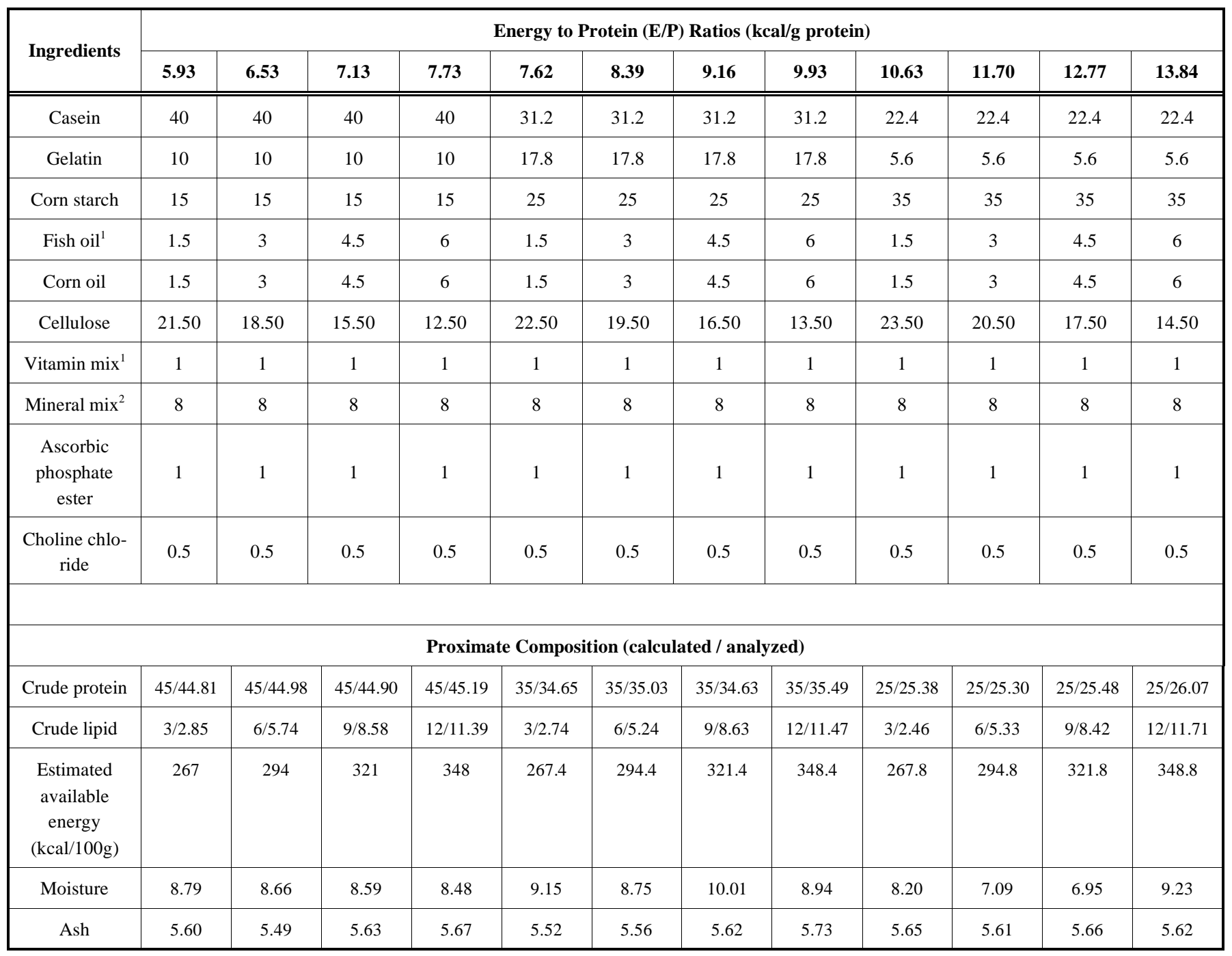

${ }^{1}$ Vitamin mix contained (mg.100g-1 of diet): thiamine HNO3, 5; riboflavin, 5; vitamin A, 2500IU; vitamin E, 40; vitamin D3, 2400IU; menadione, 4; pyridoxine $\mathrm{HCl}, 4$; cyanocobalamin, 0.01 ; biotin, 0.6 ; calcium pantothenate, 10; folic acid, 1.5; niacin, 20; inositol, 200; and cellulose was used as a carrier.

${ }^{2}$ Mineral mix: (g.100g-1 diet): calcium biphosphate, 0.98; calcium lactate, 3.79; sodium chloride, 0.26; potassium sulfate, 1.31; potassium chloride, 0.53; ferrous sulfate, 0.09 ; ferric citrate, 0.31 ; magnesium sulfate, 0.35 ; zinc sulfate, 0.004 ; manganese sulfate, 0.003 ; cupric sulfate, 0.002 ; cobalt chloride, 0.003 ; potassium iodide, 0.0002 ; and cellulose 4.2 .

and the daily rations were adjusted accordingly. Wasted feed and feces were removed from tanks with a rubber pipe every morning and were dried for feed intake calculation. The experiment lasted for 70 days (from October to December in Guangzhou, South China). During the experiment, the water temperature, dissolved oxygen, $\mathrm{pH}$ and ammonia were 22.2 $\pm 2.8^{\circ} \mathrm{C}, 7.96 \pm 0.39 \mathrm{mg} / \mathrm{L}, 7.46 \pm 0.23$ and $0.14 \pm 0.05 \mathrm{mg} / \mathrm{L}$, respectively.

\section{Sample Collection and Chemical Analysis}

At the end of the experiment, fish were weighed and weight gain (WG), specific growth rate (SGR) and feed efficiency ratio (FER) were calculated using the equals showed in footnotes in Table 2. After the final weighing, three fish were randomly sampled from each tank to determine the whole body chemical composition. Another five fish were randomly taken, killed, and body weight, body length, vis- cera, liver and intraperitoneal fat were measured, respectively. The moisture was analyzed by drying at $105^{\circ} \mathrm{C}$ for $24 \mathrm{~h}$. Protein, lipid and ash of diets and samples were analyzed by the Kjeldhal method with Tecator Kjelte (1030Auto-analyzer, Tecator AB, Höganäs,Sweden), Soxhlet Extraction with Tecator Soxtem (HT6, Tecator AB, Höganäs,Sweden) and combustion at $550^{\circ} \mathrm{C}$ for $16 \mathrm{~h}$, respectively.

\section{Statistical Analysis}

Possible effects of dietary energy and protein on fish performance were statistically analyzed using SPSS 9.0. The normality of data was estimated by using Percent-Percent plot method (P-P plot). Mean of each variables were analyzed using two-way ANOVA, to find the effect of dietary lipid (energy), protein and any possible interactions between lipid and protein levels. The significant $(\mathrm{P}<0.05)$ differences 
Table 2. Growth Performance and Feed Efficiency of Grass Carp Fed Diets with Different E/P Ratios ${ }^{1}$

\begin{tabular}{|c|c|c|c|c|c|c|c|c|}
\hline $\mathrm{DP}(\%)$ & DL (\%) / Energy (kcal/100g diet) & E/P Ratios & Initial (g) & FI $(g / \text { fish })^{2}$ & $\mathbf{W G}^{3}$ & $\mathbf{S G R}^{4}$ & FER $^{5}$ & PER $^{6}$ \\
\hline \multirow[t]{3}{*}{45} & $3 / 267$ & 5.93 & 3.28 & $8.59^{\mathrm{c}}$ & $102.20^{\mathrm{d}}$ & $1.00^{\mathrm{d}}$ & $0.39^{\mathrm{f}}$ & $0.95^{\mathrm{d}}$ \\
\hline & $9 / 321$ & 7.13 & 3.32 & $6.67^{\mathrm{a}}$ & $50.14^{\mathrm{ab}}$ & $0.58^{\mathrm{ab}}$ & $0.25^{\mathrm{bc}}$ & $0.60^{\mathrm{ab}}$ \\
\hline & $12 / 348$ & 7.73 & 3.32 & $6.44^{\mathrm{a}}$ & $41.35^{\mathrm{a}}$ & $0.49^{\mathrm{a}}$ & $0.21^{\mathrm{ab}}$ & $0.51^{\mathrm{a}}$ \\
\hline \multirow{3}{*}{35} & $6 / 294.4$ & 8.39 & 3.31 & $7.24^{\mathrm{b}}$ & $61.94^{\mathrm{bc}}$ & $0.69^{\mathrm{bc}}$ & $0.28^{\mathrm{cd}}$ & $0.89^{\mathrm{d}}$ \\
\hline & $9 / 321.4$ & 9.16 & 3.30 & $6.41^{\mathrm{a}}$ & $41.05^{\mathrm{a}}$ & $0.49^{\mathrm{a}}$ & $0.21^{\mathrm{ab}}$ & $0.66^{\mathrm{abc}}$ \\
\hline & $12 / 348.4$ & 9.93 & 3.31 & $6.36^{\mathrm{a}}$ & $35.45^{\mathrm{a}}$ & $0.43^{\mathrm{a}}$ & $0.18^{\mathrm{a}}$ & $0.56^{\mathrm{a}}$ \\
\hline \multirow[t]{2}{*}{25} & $3 / 267.8$ & 10.63 & 3.30 & $7.65^{\mathrm{b}}$ & $73.00^{\mathrm{c}}$ & $0.78^{\mathrm{c}}$ & $0.32^{\mathrm{de}}$ & $1.36^{\mathrm{f}}$ \\
\hline & $12 / 348.8$ & 13.84 & 3.32 & $6.39^{\mathrm{a}}$ & $39.13^{\mathrm{a}}$ & $0.47^{\mathrm{a}}$ & $0.20^{\mathrm{ab}}$ & $0.85^{\mathrm{cd}}$ \\
\hline \multicolumn{4}{|c|}{ ANOVA $P$} & $<0.001$ & $<0.001$ & $<0.001$ & $<0.001$ & $<0.001$ \\
\hline \multicolumn{4}{|c|}{ DP level } & $<0.001$ & $<0.001$ & $<0.002$ & $<0.003$ & $<0.001$ \\
\hline \multicolumn{4}{|c|}{ DL (Energy) Level } & $<0.001$ & $<0.001$ & $<0.001$ & $<0.001$ & $<0.001$ \\
\hline \multicolumn{4}{|c|}{$\mathrm{DP} \times \mathrm{DL}($ Energy $)$} & $<0.1$ & $<0.2$ & $<0.3$ & $<0.5$ & $<0.6$ \\
\hline \multicolumn{4}{|c|}{ Pooled SEM } & 0.51 & 5.31 & 0.048 & 0.019 & 0.065 \\
\hline
\end{tabular}

${ }^{1}$ Mean of three replicates. Numbers with different superscripts within each column are significantly different $(\mathrm{P}<0.05)$.

${ }^{2}$ Feed intake (FI)

${ }^{3}$ Weight gain $(\mathrm{WG})=($ final weight - initial weight $) \times 100 /$ (initial weight $)$

${ }^{4}$ Specific growth rate $(S G R)=(\ln$ final weight $-\ln$ initial weight $) \times 100$ /days

${ }^{5}$ Feed efficiency ratio $($ FER $)=($ Fish weight gain $) /($ feed intake $)$

${ }^{6}$ Protein efficiency ratio $($ PER $)=($ Fish weight gain $) \times 100 /($ protein intake $)$

of each variable were detected by the one-way ANOVA test, Duncan's multiple range test was used to rank the groups.

\section{RESULTS}

After a 10-week feeding trial, no fish died. Feed intake $(\mathrm{FI})$, weight gain (WG), specific growth rate (SGR), feed efficiency ratio (FER) and protein efficiency ratio (PER) are presented in Table $\mathbf{2}$ and Fig (1). All growth and feed efficiencies indices were significantly affected by the DL and DP levels. The highest FI, growth and FER were obtained with the diet containing 45\% DP and 3\% DL (E/P ratio of $5.93 \mathrm{kcal} / \mathrm{g}$ protein), followed closely by the group of $35 \%$ DP and $3 \% \mathrm{DL}$ (E/P ratio of $7.62 \mathrm{kcal} / \mathrm{g}$ protein). At the same DP level, FI, WG, SGR, FER and PER decreased with the increasing DL level. However at the same DL level, FI, WG, SGR and FER increased as the DP levels increased. At the $9 \%$ and $12 \%$ DL levels (energy of 321 and $348 \mathrm{kcal} / 100 \mathrm{~g}$ diet), the FI, WG, SGR and FER didn't show any significant differences, irrespective of the DP level. At the same DL level, PER decreased with the increase of DP level and the highest PER was obtained by the group with $25 \%$ DP and $3 \% \mathrm{DL}$ (E/P ratio of $10.63 \mathrm{kcal} / \mathrm{g}$ protein).
Data related to condition factor (CF), viscera percentage (VP), hepatosomatic index (HSI) and intraperitoneal fat ratio (IPF ratio) are presented in Table 3. CF was significantly affected by DP level $(\mathrm{P}<0.05)$, but not by DL level. With the increase of $\mathrm{E} / \mathrm{P}$ ratio, $\mathrm{CF}$ showed an increasing trend. VP and HSI were affected significantly both by DP and DL (energy) level, and they both showed an increasing trend with the arising dietary E/P ratio. IPF ratio was not affected by either DP or DL levels.

The whole body and liver composition are shown in Table 4. Neither dietary DP nor DL levels had any significant effect on crude protein of whole body $(\mathrm{P}>0.05)$. However, lipid content of whole body and liver was affected significantly by DP and DL level and tended to enhance with the increase of DL level at the same DP level. The moisture content of whole body and liver were significantly affected only by DL level, and its trend was inversely related to that of lipid content in liver.

\section{DISCUSSION}

The main purpose of this experiment was to investigate the utilization of dietary protein and energy of grass carp under low temperature. The water temperature in the present 


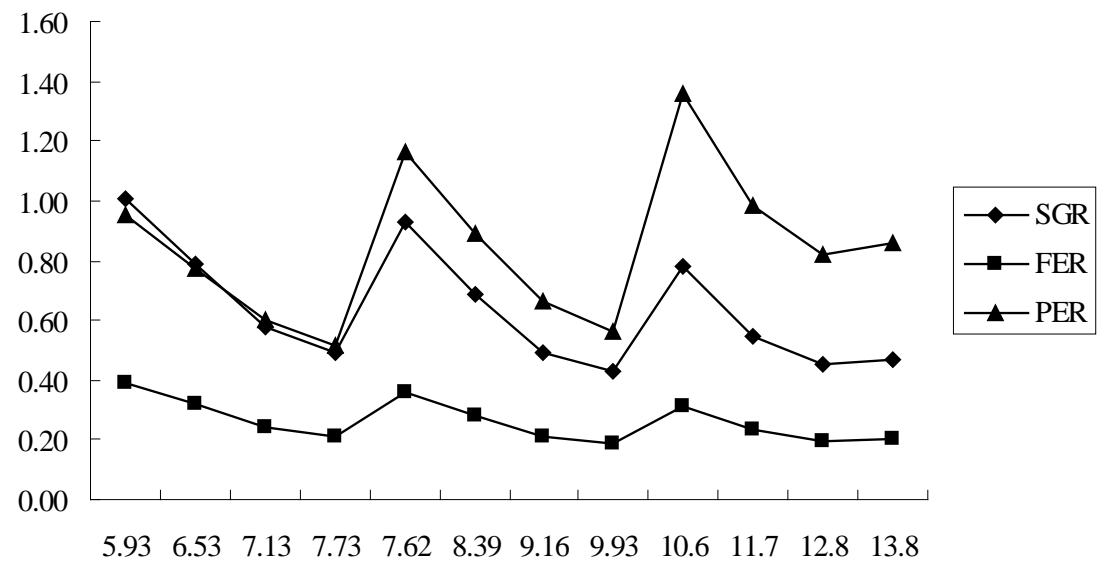

Dietary E/P ratio (kcal/g)

Fig. (1). Relationship of SGR, FER and PER to dietary E/P ratio.

Table 3. Biological Measurement of Grass Carp Fed Diets with Different E/P Ratios ${ }^{1}$

\begin{tabular}{|c|c|c|c|c|c|c|}
\hline $\mathrm{DP}(\%)$ & $\begin{array}{c}\text { DL (\%) / Energy } \\
\text { (kcal/100g diet) }\end{array}$ & E/P Ratios & $\mathbf{C F}^{2}$ & $\mathbf{V P} \mathbf{P}^{3}$ & $\mathrm{HSI}^{4}$ & IPF Ratio ${ }^{5}$ \\
\hline \multirow[t]{4}{*}{45} & $3 / 267$ & 5.93 & $2.12^{\mathrm{a}}$ & $9.66^{\mathrm{a}}$ & $3.01^{\mathrm{a}}$ & 2.13 \\
\hline & $6 / 294$ & 6.53 & $2.21^{\mathrm{ab}}$ & $10.17^{\mathrm{ab}}$ & $3.19^{\mathrm{ab}}$ & 2.27 \\
\hline & $9 / 321$ & 7.13 & $2.10^{\mathrm{a}}$ & $10.80^{\mathrm{bcd}}$ & $3.37^{\mathrm{abc}}$ & 2.22 \\
\hline & $12 / 348$ & 7.73 & $2.13^{\mathrm{a}}$ & $10.24^{\mathrm{abc}}$ & $3.23^{\mathrm{ab}}$ & 2.02 \\
\hline \multirow[t]{4}{*}{35} & $3 / 267.4$ & 7.62 & $2.17^{\mathrm{ab}}$ & $10.27^{\mathrm{abc}}$ & $3.33^{\mathrm{abc}}$ & 2.08 \\
\hline & $6 / 294.4$ & 8.39 & $2.15^{\mathrm{a}}$ & $10.56^{\mathrm{abc}}$ & $3.49^{\mathrm{abc}}$ & 2.30 \\
\hline & $9 / 321.4$ & 9.16 & $2.20^{\mathrm{ab}}$ & $10.85^{\mathrm{bcd}}$ & $3.75^{\mathrm{bcd}}$ & 2.26 \\
\hline & $12 / 348.4$ & 9.93 & $2.18^{\mathrm{ab}}$ & $11.62^{\mathrm{de}}$ & $3.90^{\mathrm{cd}}$ & 2.61 \\
\hline \multirow[t]{4}{*}{25} & $3 / 267.8$ & 10.63 & $2.29^{\mathrm{b}}$ & $11.22^{\text {cde }}$ & $3.49^{\mathrm{abc}}$ & 2.77 \\
\hline & $6 / 294.8$ & 11.70 & $2.28^{\mathrm{b}}$ & $11.71^{\mathrm{de}}$ & $4.20^{\mathrm{d}}$ & 2.35 \\
\hline & $9 / 321.8$ & 12.77 & $2.30^{\mathrm{b}}$ & $12.18^{\mathrm{e}}$ & $4.31^{\mathrm{d}}$ & 2.81 \\
\hline & $12 / 348.8$ & 13.84 & $2.23^{\mathrm{ab}}$ & $12.13^{\mathrm{e}}$ & $4.30^{\mathrm{d}}$ & 2.50 \\
\hline \multicolumn{3}{|c|}{ ANOVA $P$} & $<0.02$ & $<0.001$ & $<0.001$ & $<0.2$ \\
\hline \multicolumn{3}{|c|}{ DP level } & $<0.001$ & $<0.001$ & $<0.001$ & 1 \\
\hline \multicolumn{3}{|c|}{ DL (Energy) Level } & $<0.8$ & $<0.004$ & $<0.004$ & 1 \\
\hline \multicolumn{3}{|c|}{$\mathrm{DP} \times \mathrm{DL}($ Energy $)$} & $<0.5$ & $<0.6$ & $<0.6$ & 1 \\
\hline \multicolumn{3}{|c|}{ Pooled SEM } & 0.04 & 0.31 & 0.17 & 0.19 \\
\hline
\end{tabular}

${ }^{1}$ Mean of three replicates. Numbers with different superscripts within each column are significantly different $(\mathrm{P}<0.05)$.

${ }^{2}$ Condition factor $(\mathrm{CF})=$ Fish weight $(\mathrm{g}) \times 100 /$ body length $^{3}(\mathrm{~cm})$

${ }^{3}$ Viscera percentage $(\mathrm{VP})=$ Viscera weight $\times 100 /$ fish weight

${ }^{4}$ Hepatosomatic index $(\mathrm{HSI})=$ Liver weight $\times 100 /$ fish weight

${ }^{5}$ Intraperitoneal fat ratio (IPF ratio) $=$ Intraperitoneal fat weight $\times 100 /$ fish weight

study $\left(22^{\circ} \mathrm{C}\right)$ was lower than the optimum temperature (about $27-28^{\circ} \mathrm{C}$ ) of grass carp, and it was the main reason that the growth rate of this experiment was lower than those of summer [21]. But it was the real condition in grass carp aquaculture from October to December in south China and results still seem helpful for practical aquaculture for this part of the year.

In the present study, feed intake and growth performance of grass carp decreased as DL level increased at the same DP 
Table 4. Composition of Whole Body and Liver in Grass Carp Fed Diets with Different E/P Ratios ${ }^{1}$

\begin{tabular}{|c|c|c|c|c|c|c|c|}
\hline $\mathrm{DP}(\%)$ & $\begin{array}{c}\text { DL (\%) / Energy } \\
\text { (kcal/100g diet) }\end{array}$ & E/P Ratios & \multicolumn{3}{|c|}{ Whole Body } & \multicolumn{2}{|c|}{ Liver } \\
\hline \multirow[t]{3}{*}{45} & $3 / 267$ & 5.93 & $77.84^{\mathrm{bc}}$ & 13.88 & $4.00^{\mathrm{a}}$ & $69.87^{\mathrm{f}}$ & $4.30^{\mathrm{ab}}$ \\
\hline & $6 / 294$ & 6.53 & $76.57^{\mathrm{bc}}$ & 14.56 & $4.04^{\mathrm{a}}$ & $68.80^{\text {def }}$ & $6.28^{\text {cde }}$ \\
\hline & $9 / 321$ & 7.13 & $78.84^{\mathrm{c}}$ & 13.65 & $4.99^{\mathrm{b}}$ & $67.28^{\mathrm{cd}}$ & $7.53^{\mathrm{e}}$ \\
\hline \multirow[t]{3}{*}{35} & $3 / 267.4$ & 7.62 & $78.16^{\mathrm{bc}}$ & 13.77 & $4.01^{\mathrm{a}}$ & $69.63^{\mathrm{f}}$ & $3.39^{\mathrm{a}}$ \\
\hline & $6 / 294.4$ & 8.39 & $77.20^{\mathrm{bc}}$ & 14.11 & $6.36^{\mathrm{cd}}$ & $69.27^{\mathrm{ef}}$ & $4.41^{\mathrm{abc}}$ \\
\hline & $9 / 321.4$ & 9.16 & $76.52^{\mathrm{bc}}$ & 13.94 & $6.60^{\mathrm{d}}$ & $67.32^{\mathrm{cd}}$ & $6.01^{\text {bde }}$ \\
\hline \multirow{2}{*}{25} & $9 / 321.8$ & 12.77 & $76.64^{\mathrm{bc}}$ & 13.32 & $5.48^{\mathrm{b}}$ & $67.00^{c}$ & $6.97^{\mathrm{de}}$ \\
\hline & $12 / 348.8$ & 13.84 & $73.81^{\mathrm{a}}$ & 14.62 & $6.76^{\mathrm{d}}$ & $63.96^{\mathrm{ab}}$ & $9.97^{\mathrm{f}}$ \\
\hline \multicolumn{3}{|c|}{ ANOVA $P$} & $<0.04$ & $<0.1$ & $<0.001$ & $<0.001$ & $<0.001$ \\
\hline \multicolumn{3}{|c|}{ DP level } & $<0.2$ & 1 & $<0.001$ & $<0.2$ & $<0.04$ \\
\hline \multicolumn{3}{|c|}{ DL (Energy) Level } & $<0.03$ & 1 & $<0.001$ & $<0.001$ & $<0.001$ \\
\hline \multicolumn{3}{|c|}{$\mathrm{DP} \times \mathrm{DL}($ Energy $)$} & $<0.2$ & 1 & $<0.001$ & $<0.4$ & $<0.3$ \\
\hline
\end{tabular}

${ }^{1}$ Mean of three replicates. Numbers with different superscripts within each column are significantly different $(\mathrm{P}<0.05)$.

level, and the best growth was obtained in diet containing the lowest GE. It suggests that grass carp has low capacity to utilize dietary lipid as an energy source which is in agreement with the previous studies [18, 21]. Lovell [1] demonstrated when fish was fed a diet containing excess energy, growth might be reduced due to reduced feed consumption. In the present study, the uneaten feed was also found at the bottom of groups fed diet containing DL level exceeding $9 \%$ (GE exceeding $321 \mathrm{kcal} / 100 \mathrm{~g}$ diet) which was also represented by the data of decreased feed intake in Table $\mathbf{2}$. It is assumed that fish, as well as homoeothermic animals [22] can adjust their feed intake to satisfy their digestible energy requirements [23, 24]. Higher water temperature increases the demand for energy for maintenance and activity of fish [25]. In contrast, $\mathrm{Ng}$ et al. [26] demonstrated that low water temperature decreased the digestibility of dietary lipids, especially saturated fatty acids, whereas increase the content of triglyceride in the fecal lipids of rainbow trout. Taking into account the above information, low water temperature of the present study might reduce the energy requirement of fish and high dietary lipid level (or energy level) may not be suitable for grass carp in cold reason. On the other hand, since the food of grass carp in natural environment is water plant with low energy, the relative low capacity to utilize dietary lipid in grass carp is conceivable.

Protein-sparing effect of dietary lipid was not obviously found in the present study. When DL level was $3 \%$ or $6 \%$, growth performance of groups with higher DP and lower DL levels were always better than that of groups with lower DP and higher DL levels. Meanwhile, when DL level was $9 \%$ or $12 \%$, the growth rate of all treatments were not significantly different, but are much lower than the groups with lower DL level.

Our summer experiments [21] showed that grass carp was sensitive to DL level, and high DL content would induce excess lipids accumulation of liver. This result was also consistent with the results from the present experiment in cold season. With the increase of dietary lipid level, the lipid content in liver increased rapidly, even faster than the increase of our summer data. It is suggested that in the cold season, the energy utilization of grass carp is lower than that in warm season and it also implies that hepatic symptom induced by high fat diet would be more easily happened in cold season.

Improved growth and feed efficiency ratio with increasing dietary protein level is well known in many species [27]. 
In the present study, WG, SGR and FER were also improved with the increasing DP level at the DL levels below $12 \%$. Our previous work (unpublished data) found the optimum protein requirement of juvenile grass carp is $38 \%$ when water temperature is $25.5^{\circ} \mathrm{C}$. In the present study, $35 \%$ DP level was similar with the optimum protein requirement attained from our previous work, and the higher protein level (45\%) might have no additional growth response. Millikin [28] obtained that PER of striped bass increased as both dietary protein and lipid increased from 37 to $57 \%$ and 7 to $17 \%$, respectively. However, in the present study, PER of grass carp decreased as both dietary protein and lipid increased from 25 to $45 \%$ and 3 to $12 \%$, respectively. This result also differs from yellowtail [29], red drum [3] and partly differs from Atlantic cod [30], in which PER had negative and positive correlation with dietary protein and lipid level, respectively. Considering the different feeding habit of fish, it is suggested that herbivorous grass carp has a lower capacity to utilize excess protein and lipids than other carnivorous or omnivorous fish.

Dietary E/P is an important criterion in fish feed formulation. Optimum dietary E/P ratios for some fish species were investigated and the estimated ratios range from 8.9 to 12.3 $\mathrm{kcal} / \mathrm{g}$ protein [27]. In the present study, the maximum growth and feed efficiency ratio was obtained in the group with $45 \%$ DP, $3 \%$ DL and E/P ratio of $5.93 \mathrm{kcal} / \mathrm{g}$ protein and the group with $35 \% \mathrm{DP}, 3 \% \mathrm{DL}$ and $\mathrm{E} / \mathrm{P}$ ratio of 7.62 $\mathrm{kcal} / \mathrm{g}$ protein. These E/P ratios are lower than the optimum E/P ratios of several species investigated [27], and it confirms again that grass carp has lower dietary energy requirement. According to Table $\mathbf{1}$ and the Fig. (1), it is obvious that the growth of fish didn't correlate with E/P ratio linearly, which indicate that actual amount of dietary protein and energy must be carefully considered when optimum E/P ratio is estimated. This is also similar to the observation on rockfish [31].

The results of this study indicate that at cold season, juvenile grass carp grows well by the diets containing $45 \%$ protein, $3 \%$ lipid, E/P ratio of $5.93 \mathrm{kcal} / \mathrm{g}$ protein and GE of $267 \mathrm{kcal} / 100 \mathrm{~g}$ diet or $35 \%$ protein, 3\% lipid, E/P ratio of $7.62 \mathrm{kcal} / \mathrm{g}$ protein and GE of $267 \mathrm{kcal} / 100 \mathrm{~g}$ diet. Taking into account the cost of feeding, the latter diet is recognized as an optimal one for juvenile grass carp in the present study.

\section{REFERENCES}

[1] Lovell RT. Nutrition and Feeding of Fish. Van Nostrand-Reinhold: New York, 1989.

[2] De Silva SS, Gunasekera RM, Shim KF. Interactions of varying dietary protein and lipid levels in young red tilapia: evidence of protein sparing. Aquaculture 1991; 95: 305-18.

[3] Daniels WH, Robinson EH. Protein and energy requirement of juvenile red drum (Sciaenops ocellatus). Aquaculture 1986; 53: 243-52.

[4] Garling DL, Wilson RP. Optimum dietary protein to energy ratio for channel catfish fingerlings, Ictalurus punctatus. J Nutr 1976; 106: 1368-75.

[5] El-Sayed AM, Teshima S. Protein and energy requirements of Nile tilapia, Oreochromis niloticus, fry. Aquaculture 1992; 103: 55-63.

[6] Winfree RA, Stickney RR. Effects of dietary protein and energy on growth, feed conversion efficiency, and body composition of $T$. aurea. J Nutr 1981; 111: 1001-12.

[7] Nematipour GR, Brown ML, Gatlin DM. Effects of dietary energy: protein ration on growth characteristics and body composition of hybrid striped bass, Morone chrysops $\times$ M. saxatilis. Aquaculture 1992; 107: 359-68.

[8] Henken AM, Machiels MA, Dekker W, Hogendoon H. The effect of dietary protein and energy content on growth rate and feed utilization of the African catfish, Clarias gariepinus (Burchell 1822). Aquacultrue 1986; 58: 55-74.

[9] Catacutan MR, Coloso RM. Effect of dietary protein to energy ratios on growth, survival, and body composition of juvenile Asian seabass, Lates calcarifer. Aquaculture 1995; 131: 125-33.

[10] Carter CG, Brafield AR. The bioenergetics of grass carp Ctenopharyngodon idella (Val.): energy allocation at different planes of nutrition. J Fish Biol 1991; 39: 873-87.

[11] Carter CG, Brafield AR. The bioenergetics of grass carp Ctenopharyngodon idella (Val.): the influence of body weight, ration and dietary composition on nitrogenous excretion. J Fish Biol 1992a; 41: 533-43.

[12] Carter CG, Brafield AR. The relationship between specific dynamic action and growth in grass carp Ctenopharyngodon idella (Val.). J Fish Biol 1992b; 41: 895-907.

[13] Cui Y, Liu XF, Wang SM, Chen SL. Growth and energy budget in young grass carp Ctenopharyngodon idella Val. fed plant and animal diets. J Fish Biol 1992; 41: 231-238.

[14] Dabrowski K. Protein requirement of grass carp fry (Ctenopharyngodon idella Val.). Aquaculture 1977; 12: 63-73.

[15] Dabrowski K, Kozak B. The use of fish meal and soybean meal as a protein source in the diet of grass carp fry. Aquaculture 1979; 18: 107-14.

[16] Lin D, Mao YQ, Liao XH. Improvement of meat quality of grass carp (Ctenopharyngodon idellus.) In: De Silva SS, Eds. Fish Nutrition Research in Asia. Proceeding of the Third Asian Fish Nutrition Network Meeting; 1988, Asian Fisheries Society, Bangkok, 1989; pp.148-52.

[17] Lin D. Grass carp, Ctenopharyngodon idella. In: Wilson RP, Ed. Handbook of Nutrient Requirement of Finfish, CRC Press 1991; 89-96.

[18] Du ZY, Liu YJ, Tian LX, Wang JT, Wang Y, Liang GY. Effect of dietary lipid level on growth, feed utilization and body composition by juvenile grass carp (Ctenopharyngodon idella). Aquacult Nutr 2005; 11: 179-88.

[19] Lee DJ, Putnam GB. The response of rainbow trout to varying protein/energy ratios in a test diet. J Nutr 1973; 103: 916-22.

[20] Garling DL, Wilson RP. Effect of dietary carbohydrate to lipid ratio on growth and body composition of fingerling channel catfish. Prog Fish-Cult 1977; 39: 43-7.

[21] Du ZY, Clouet P, Huang LM, Degrace P, Zheng WH, Tian LX, Liu YJ. Utilization of different dietary lipid sources at high level in herbivorous grass carp (Ctenopharyngodon idella): mechanism related to hepatic fatty acid oxidation. Aquacult Nutr 2008; 14: 7792.

[22] Kissileff HR, Van Itallie TB. Physiology of the control of food intake. Ann Rev Nutr 198; 22: 371-418.

[23] Cho CY, Kaushik SJ. Effects of protein intake on metabolizable and net energy values of fish diets. In: Cowey CB, Mackie AM, Bell JG, Eds. Nutrition and Feeding in Fish. Proceedings of international symposium on fish feeding and nutrition, Aberdeen: London 1985; pp. 95-117.

[24] Kaushik SJ, Medale F. Energy requirements, utilization and dietary supply to salmonids. Aquaculture 1994; 124: 81-97.

[25] Weatherley AH, Gill HS. The biology of fish growth. Academic Press: London 1987.

[26] Ng WK, Campbell PJ, Dick JR, Bell JG. Interactive effects of dietary palm oil concentration and water temperature on lipid digestibility in rainbow trout, Oncorhynchus mykiss. Lipids 2003; 38: 1031-38.

[27] National Research Council. Nutrient Requirement of Fish. National Academy Press: Washington 1993.

[28] Millikin MR. Interactive effects of dietary protein and lipid on growth and protein utilization of age-0 striped bass. Trans Am Fish Soc 1983; 111: 373-8.

[29] Takeda M, Shimeno S, Hosokawa H, Kajiyama H, Kaisyo T. The effect of dietary calorie to protein ratio on growth, feed conversion 
and body composition of young yellowtail. Bull Jpn Soc Sci Fish 1975; 41: 443-7.

[30] Morais S, Bell JG, Robertson DA, Roy WJ, Morris RC. Protein / lipid ratios in extruded diets for Atlantic cod (Gadus morhua L.): effects of growth, feed utilization, muscle composition and liver histology. Aquaculture 2001; 203: 101-19.
[31] Lee SM, Jeon IG, Lee JY. Effects of digestible protein and lipid levels in practical diets on growth, protein utilization and body composition of juvenile rockfish (Sebastes schlegeli). Aquacalture 2002; 211: 227-39.

Received: November 17, 2008

Revised: January 05, 2009

Accepted: January 12, 2009

(C) Du et al.; Licensee Bentham Open.

This is an open access article distributed under the terms of the Creative Commons Attribution License (http://creativecommons.org/licenses/by/2.5/), which permits unrestrictive use, distribution, and reproduction in any medium, provided the original work is properly cited. 